
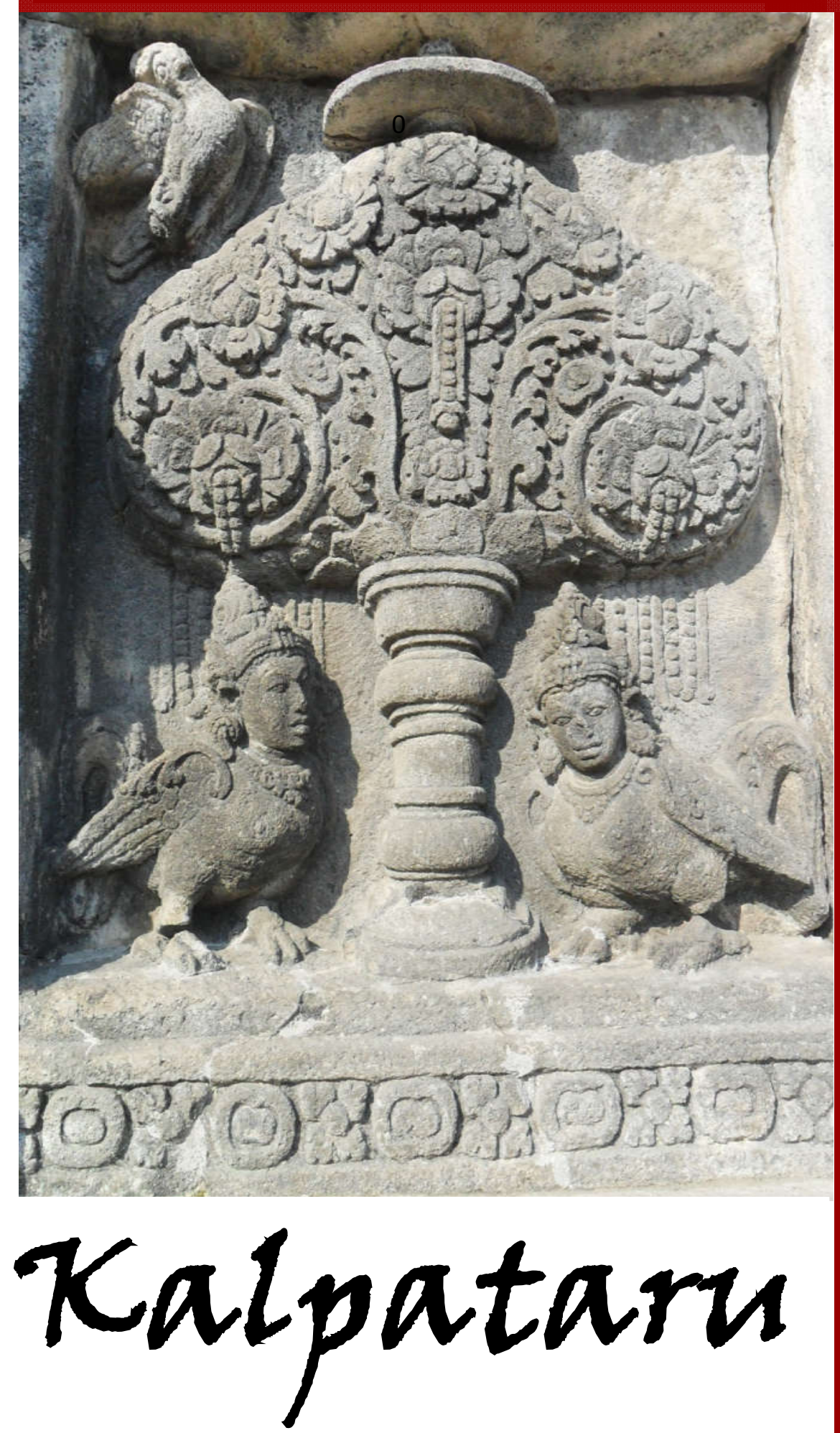

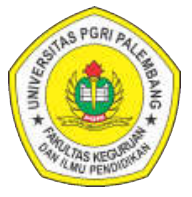

Program Studi Pendidikan Sejarah Jurusan Pendidikan IPS

Fakultas Keguruan dan IImu Pendidikan Universitas Persatuan Guru Republik Indonesia Palembang
Pengembangan Media Audio Visual Sejarah Islam Materi Masjid Agung Palembang

Septia Puspita, Sukardi

Pengembangan Media Pembelajaran Sejarah dengan Doodle Art pada Materi Sejarah Lokal Semende

Ahmad Robbin, Aan Suriadi

Perancangan Video Informasi Candi Kalasan

Kevin Ronald Pattipawae, Anthony Y.M. Tumimomor

Akulturasi Budaya Hindu-Budha dan Islam dalam Sejarah Kebudayaan Palembang

Muhamad Idris, Eva Dina Chairunisa, Riki Andi Saputro

Sejarah Terbentuknya Kepulauan Bangka Belitung (Pangkal Pinang) sebagai Sumber Pembelaran Sejarah

Yoga Abimayu, Dina Srinindiati

Kiprah Depati Amir (Pahlawan Nasional Bangka Belitung) Melawan Belanda dari Tahun 1830-1851 Masehi sebagai Sumber Pembelajaran Sejarah di SMA Negeri 1 Lepar Pongok Jutria, Sukardi

Metafora dalam Kebudayaan Islam Melayu Sumatera Selatan

Muhamad Idris

Pengembangan Media Peta Bentuk Puzzle dengan Memanfaatkan Plastik Kemasan Makanan Ringan pada Mata Pelajaran Sejarah

Muhammad Rehan Pradana, Muhamad Idris

Pengembangan E-Modul Pembelajaran Sejarah Perjuangan Tokoh-Tokoh Militer Pejuang Kemerdekaan di Sumatera Selatan

Devi Putrianata, Eva Dina Chairunisa

Buku Komik Lokal Sebagai Media Pengenalan Kearifan Lokal Sumatera Selatan (Lahat) Pada Anak Sekolah Dasar Ummi Charlina, Riska Anggraini, Sapta Herawati 


\title{
Kalpataru
}

\section{Jurnal Sejarah dan Pembelajaran Sejarah}

Volume 5, Nomor 2, Desember 2019

\section{Penanggung Jawab}

Dr. Dessy Wardiah, M.Pd.

\section{Ketua Dewan Redaksi}

Drs. Sukardi, M.Pd.

\section{Penyunting Pelaksana}

Dr. Muhamad Idris, M.Pd.

Eva Dina Chairunisa, M.Pd.

Jeki Sepriady, S.Pd.

Dr. Tahrun, M.Pd.

Drs. Supriyanto, M.Hum.

Dra. Retno Purwati, M.Hum.

Dr. Nor Huda Ali, M.Ag., M.A.

Dr. Budi Agung Sudarman, S.S., M.Pd.

Dr. Purmansyah, M.A.

\section{Penyunting Ahli}

(Universitas PGRI Palembang)

(Universitas Sriwijaya Palembang)

(Balai Arkeologi Sumatera Selatan)

(Masyarakat Sejarawan Indonesia Sumsel)

. (Balai Bahasa Provinsi Sumatera Selatan)

(Universitas Muhammadiyah Palembang)

\author{
Alamat Redaksi \\ Program Studi Pendidikan Sejarah \\ Jurusan Pendidikan IImu Pengetahuan Sosial \\ Fakultas Keguruan dan IImu Pendidikan Universitas PGRI Palembang \\ Telp. 0711-510043 \\ Email: jurnalkalpatarusejarah@gmail.com \\ Website: https://jurnal.univpgri-palembang.ac.id/index.php/Kalpa
}




\section{Kalpataru}

JURNAL SEJARAH DAN

PEMBELAJARAN SEJARAH

Terbit dua kali setahun pada Juli dan Desember

Diterbitkan oleh:

Program Studi Pendidikan Sejarah Jurusan Pendidikan IPS

Fakultas Keguruan dan IImu Pendidikan

Universitas PGRI Palembang

\section{DAFTAR ISI}

Pengembangan Media Audio Visual Sejarah Islam Materi Masjid Agung Palembang

Septia Puspita, Sukardi

Pengembangan Media Pembelajaran Sejarah dengan

Doodle Art pada Materi Sejarah Lokal Semende

Ahmad Robbin, Aan Suriadi. $86-94$

Perancangan Video Informasi Candi Kalasan

Kevin Ronald Pattipawae, Anthony Y.M. Tumimomor.

Akulturasi Budaya Hindu-Budha dan Islam dalam

Sejarah Kebudayaan Palembang

Muhamad Idris, Eva Dina Chairunisa, Riki Andi Saputro.

Sejarah Terbentuknya Kepulauan Bangka Belitung (Pangkal Pinang) sebagai Sumber Pembelaran Sejarah Yoga Abimayu, Dina Srinindiati.

Kiprah Depati Amir (Pahlawan Nasional Bangka Belitung) Melawan Belanda dari Tahun 1830-1851 Masehi sebagai Sumber Pembelajaran Sejarah di SMA Negeri 1 Lepar Pongok

Jutria, Sukardi.

Metafora dalam Kebudayaan Islam Melayu Sumatera

Selatan

Muhamad Idris.

$126-140$

Pengembangan Media Peta Bentuk Puzzle dengan

Memanfaatkan Plastik Kemasan Makanan Ringan pada

Mata Pelajaran Sejarah

Muhammad Rehan Pradana, Muhamad Idris

Pengembangan E-Modul Pembelajaran Sejarah

Perjuangan Tokoh-Tokoh Militer Pejuang

Kemerdekaan di Sumatera Selatan

Devi Putrianata, Eva Dina Chairunisa

Buku Komik Lokal Sebagai Media Pengenalan Kearifan Lokal Sumatera Selatan (Lahat) Pada Anak Sekolah Dasar

Ummi Charlina, Riska Anggraini, Sapta Herawati $158-162$

Koleksi: Muhamad Idris 


\title{
SEJARAH TERBENTUKNYA KEPULAUAN BANGKA BELITUNG (PANGKAL PINANG) SEBAGAI SUMBER PEMBELARAN SEJARAH
}

\author{
Yoga Abimayu \\ Mahasiswa Program Studi Pendidikan Sejarah FKIP Universitas PGRI Palembang \\ Email: yoga.abimayu96@gmail.com \\ Dina Srinindiati \\ Mahasiswa Program Studi Pendidikan Sejarah FKIP Universitas PGRI Palembang \\ Email: dinamrsyid@gmail.com
}

\begin{abstract}
ABSTRAK
Pulau Bangka dan Pulau Belitung merupakan dua pulau besar yang menjadi bagian dari wilayah Provinsi Kepulauan Bangka Belitung, selain pulau-pulau kecil lainnya. Letak wilayah provinsi ini adalah $104^{\circ} 50^{\prime}$ sampai 109³0' Bujur Timur dan 0`50' sampai 4¹0' Lintang Selatan. Batas wilayah Provinsi Kepulauan Bangka Belitung adalah sebagai berikut: Barat: Selat Bangka, Timur: Selat Karimata, Utara: Laut Natuna, Selatan: Laut Jawa. Rumusan masalah dalam penelitian ini adalah nilai sejarah apakah di Provinsi Kepulauan Bangka Belitung yang dapat dijadikan sebagai sumber pembelajaran sejarah?. Penelitian ini bertujuan untuk untuk mengetahui nilai sejarah terbentuknya Provinsi Kepulauan Bangka Belitung yang dapat di jadikan sumber pembelajaran sejarah. Penelitian ini menggunakan metode penelitian deskristif kualitatif. Hasil penelitian ini adalah Provinsi Kepulauan Bangka Belitung atau biasa disingkat Babel merupakan provinsi ke-31 di Indonesia, sebelumnya merupakan bagian dari Provinsi Sumatera Selatan. Dasar hukum penetapan Provinsi Kepulauan Bangaka Belitung adalah UU No. 27 Tahun 2000 tanggal 21 November 2000 yang terbagi kedalam tiga wilayah administratif, yaitu Kabupaten Bangka, Kabupaten Belitung dan Kota Pangkal Pinang. Kemudian, di tahun 2003 dilakukan pemekaran wilayah dengan penambahan empat kabupaten yaitu Bangka Barat, Bangka Tengah, Bangka Selatan dan Belitung Timur. Hal ini didasarkan pada UU No. 5 Tahun 2003 tanggal 23 Januari 2003.
\end{abstract}

Kata Kunci: Sejarah Terbentuknya Kepulauan Bangka Belitung, Pembelajaran Sejarah.

\section{A. PENDAHULUAN}

Kepulauan Bangka Belitung sebelum menjadi sebuah provinsi adalah suatu wilayah yang tergabung dalam Provinsi Sumatera Selatan. Pada tahun 1933 Bangka Belitung berstatus Keresidenan dan merupakan Negara bagian pada masa RIS. Pada tahun 1956, Bangka Belitung ditetapkan kembali menjadi wilayah keresidenan dalam Provinsi Sumatera Selatan. Sama halnya dengan Lampung dan Bengkulu, selanjutnya pada masa penjajahan Belanda daerah ini juga ditetapkan sebagai keresidenan. Sejak tahun 1956, sebagai sebuah respon atas UU darurat nomor 4 tahun 1956, rakyat Bangka Belitung mulai menuntut pembentukan suatu provinsi sendiri, mau terlepas dari Provinsi Sumatera Selatan, maka pada tahun 1956 rakyat Bangka Belitung berjuang dengan segala kemampuan tetapi belum juga berhasil, harapan masyarakat Bangka Belitung menjadi provinsi terwujud setelah reformasi. Pada tanggal 21 November 2000. Kepulauan Bangka Belitung resmi menjadi provinsi yang merupakan provinsi ke-31 di Indonesia dengan ibu kota Pangkal Pinang. Pulau Bangka Belitung adalah sebuah nama yang diambil dari dua kepulauan yaitu Bangka dan Belitung (Elvian, 2014).

Salah satu kota di pulau Bangka yaitu Kota Pangkal Pinang mulai disebut dalam literatur sekitar abad 17 Masehi, Toponim Pangkal Pinang secara etimologis berasal dari kata Pangkal atau Pengkal dalam bahasa Bangka yang berarti pusat distrik 
(Distric Capital), kota tempat atau pasar (Market Town), tempat berlabu Kapal (A Boat Landing) dan pusat segala aktifitas dimulai (Where A Path Begin). Sebagai pusat segala aktifitas di atas sebutan Pangkal atau Pengkal juga digunakan oleh orang Bangka untuk penyebutan daerahdaerah seperti Pangkal Bulo, Pangkal Raya. Pangkal Menduk, Pangkal Manggas, Pangkal Lihat yang kemudian menjadi Sungai Lihat atau Sungai Liat sekarang, di samping sebutan Pangkal Pinang sendiri. Sedangkan Pinang (areca chatecu) adalah nama sejenis tumbuhan Palam yang multi fungsi dan banyak tumbuh di Bangka. Jadi penamaan Pangkal Pinang dimulai dari terbentuknya kampong kecil yang banyak ditumbuhi pohon Pinang. $\mathrm{Di}$ tengah kampung kecil tersebut mengalir sungaisungai yang airnya bening. Banyak perahu atau Wangkang yang keluar masuk dari kampong kecil itu, dan di tepi sungai-sungai tersebut banyak pula ditumbuhi pohon Pinang. Oleh pengguna perahu atau Wangkang, pohon Pinang tersebut digunakan untuk menambat perahu mereka ketika berlabuh (Elvian, 2014).

Pada masa Kesultanan Palembang Darussalam sudah menjadi pusat segala aktifitas kegiatan dan pemukiman. Pada tahun 1813 ketika Inggris berkuasa di Bangka, Inggris (East India Company) menjadikan Pangkal Pinang sebagai salah satu distrik. Distrik dari tujuh distrik eksplorasi timah yang produktif di samping Jebus, Klabat, Sungai Liat, Merawang, Toboali dan Belinyu. Setelah perjanjian London tanggal 13 Agustus 1814, ketika Kesultanan Palembang dan daerah-daerah lainnya termasuk Pulau Bangka diserahkan Inggris kepada Belanda sebagai ganti Cothin di India, oleh pemerintah Hindia Belanda, Pangkal Pinang dijadikan salah satu distrik penghasil timah yang produktif.

Sebagai salah satu distrik Pangkal Pinang dipimpin seorang administrateur yang merangkap kepala pemerintahan sipil distrik. Sejak itu Pangkal Pinang mulai berkembang sebagai pusat kegiatan perdagangan dan pertambangan. Lambat laun kampung yang pada awal mula terbentuknya hanyalah berupa pangkalan (Parit) pengumpul timah, daerahnya berawa-rawa dan dibelah oleh sungaisungai (diantaranya Sungai Rangkui, Sungai Pedingdang) yang dapat dilalui Wangkang atau kapal-kapal kecil hingga ke muara, terus tumbuh dan berkembang menjadi kampung besar, terbukti pada tahun 1848 jumlah penduduk Pangkal Pinang sekitar 6.694 orang, yang terbesar di 105 kampung (Elvian, 2016).

Setelah ditandatangani Konstitusi Republik Indonesia Serikat (RIS) pada Tanggal 14 Desember 1949 dan berdasarkan konstitusi ini negara berbentuk federasi dan meliputi seluruh daerah Indonesia, yaitu daerah bersama meliputi daerah-daerah seperti: Jawa Tengah, Bangka, Belitung, Riau, Daerah Istimewa Kalimantan Barat, Dayak Besar, Daerah Banjar, Kalimantan Tenggara dan Kalimantan Timur merupakan satuan-satuan kenegaraan yang tegak sendiri disamping Negara Republik Indonesia kemudian negara-negara federal bentukan Belanda serta daerah-daerah Indonesia selebihnya yang bukan daerah-daerah bagian.

Pada tanggal 22 April 1950 diangkatlah R. Soemardjo sebagai residen Bangka, Pulau Bangka ditetapkan menjadi kabupaten yang terdiri atas 5 (lima) kewedanaan dan 13 (tiga belas) kecamataan. Kewedanaan tersebut meliputi Bangka Utara yang beribukota di Belinyu, Kewedanaan Sungai Liat yang beribukota di Sungai Liat, Kewedanaan Bangka Tengah beribukota di Pangkal Pinang, Kewedanaan Bangka Barat beribukota di Mentok dan Kewedanaan Bangka Selatan beribukota di Toboali.

Sejarah Pangkal Pinang secara mendasar tidak dapat dipisahkan dari pengaruh kekuasaan Kekaisaraan Tiongkok di Asia Timur dan perebutan, penguasaan atau eksploitasai terhadap biji timah oleh 
berbagai bangsa. Sebagai bukti dari kedua hal tersebut di atas dapat dilihat dari monumen hidup (living monument), diantaranya terdapat kelenteng yang tersebar hampir di setiap rumah orang Cina dan di seluruh pelosok kota dalam ukuran besar dan kecil sesuai dengan fungsi dan pengunaanya.

\section{B. METODE PENELITIAN}

Peneliti menggunakan metode penelitian deskristif kualitatif, yang menggunakan cara mengumpulkan sumbersumber secara sistematis dan menggunakan sumber data secara mendalam. Penelitian desristif kualitataif diuraikan dengan kata-kata menurut responden, apa adanya sesuai dengan pertanyaan penelitianya, kemudian dianalisis dengan kata-kata apa yang melatarbelakangi responden berperilaku (berpikir, berperasan dan bertindak) seperti itu tidak seperti lainnya, direduksi, ditriangulasi, disimpulkan (diberi makna oleh peneliti) dan diverifikasi (dikonsultasikan kembali kepada responden dan teman sejawat). Minimal ada tiga hal yang digambarkan dalam penelitian kualitatif yaitu karakteristik, pelaku kegiatan, atau kejadian yang terjadi selama penelitian dan keadaan lingkungan atau karakteristik tempat penelitian berlangsung (Sugiyono, 2007).

\section{Teknik Pengumpulan Data Dokumentasi}

Dokumentasi merupakan catatan peristiwa yang sudah berlalu. Dokumen bisa berbentuk tulisan, gambar, atau karya-karya monumental dari seseorang. Dokumen yang berbentuk tulisan misalnya catatan harian, sejarah hidup (life historis), cerita, biografi, peraturan, kebijakan.

\section{Observasi}

Observasi adalah pengamatan dan pencatatan suatu obyek dengan sistematika fenomena yang diselidiki. Observasi dapat dilakukan sesaat ataupun mungkin dapat diulang. Oleh sebab itu observasi hendaknya dilakukan oleh orang yang tepat (Sukandarramudi, 2012: 69).

Observasi digunakan untuk menggali data dari sumber data yang berupa peristiwa, aktivitas, perilaku, tempat atau lokasi, dan benda, serta rekaman gambar. Observasi dapat dilakukan baik secara langsung maupun tidak langsung. Pada observasi langsung dapat dilakukan oleh pengumpul data dengan mengambil peran atau tak berperan. Spradley (1980) menjelaskan bahwa pelaksanaan teknik dalam observasi dapat dibagi menjadi: 1) tak berperan sama sekali, 2) observasi berperan, yang terdiri dari a) berperan pasif, b) berperan aktif, dan c) berperan penuh, dalam arti peneliti benar-benar menjadi warga (bagian) atau anggota kelompok yang sedang diamati (Sutopo, 2016: 75).

\section{Wawancara}

Wawancara adalah merupakan pertemuan dua orang untuk bertukar informasi dan ide melalui tanya jawab, sehingga dapat dikontruksikan makna dalam suatu topik tertentu (Sugiyono, 2007: 72). Wawancara digunakan sebagai teknik pengumpulan data apabila peneliti ingin melakukan studi pendahuluan untuk menentukan permasalahan yang harus diteliti, dan juga apabila peneliti ingin mengetahui hal-hal dari responden yang lebih mendalam dan jumlah respondennya sedikit, teknik pengumpulan data ini mendasarkan diri pada laporan tentang diri sendiri atau self-report, atau setidaktidaknya pada pengetahuan dan keyakinan pribadi (Sugiyono, 2013: 188).

\section{Teknik Analisis Data}

Dalam penelitian deskriptif kualitatif, data diperoleh dari berbagai sumber, dengan menggunakan teknik pengumpulan data yang bermacam-macam dan dilakukan secara terus menerus sampai datanya jenuh, dengan pengamatan yang terus menerus tersebut mengakibatkan variasi 
data tinggi sekali. Data yang diperoleh pada umumnya adalah data kualitatif (walaupun tidak menolak data kuantitatif), sehingga dengan teknik analisis data yang digunakan belum ada polanya yang jelas. Oleh karena itu, sering mengalami kesulitan dalam melakukan analisis. Seperti dinyatakan oleh Miles and Huberman (1984). Bahwa yang paling serius dan sulit dalam analisis data kualitatif adalah karena, metode analisis belum dirumuskan dengan baik. Selanjutnya Susan Stainback menyatakan: belum ada panduan dalam penelitian kualitatif untuk menentukan berapa banyak data dan analisis yang diperlukan untuk mendukung kesimpulan atau teori (Sugiyono, 2013: 220).

\section{HASIL DAN PEMBAHASAN Bangka bagian dari Sumatera Selatan}

Pada 17 Agustus 1945 Indonesia merdeka, pada masa itu Bangka masih berada dalam wilayah Provinsi Sumatera bagian Selatan. Dua tahun kemudian terbentuknya beberapa Provinsi Sumatera bagian Selatan yaitu; Provinsi Sumatera Tengah, Provinsi Sumatera Timur, dan Provinsi Sumatera Utara. Sedangkan Bangka yang termasuk Pangkal Pinang itu masuk bagian Provinsi Sumatera bagian Selatan. Ada beberapa keresidenan di dalam wilayah Provinsi Sumatera bagian Selatan itu seperti: Keresidenan Lampung, Keresidenan Bengkulu, Keresidenan Bangka Belitung, Keresidenan Palembang (Hasil wawancara oleh Bapak Elvian, 28 Mei 2019).

Sekitar tahun 1950-1960 Keresidenan Lampung dan Bengkulu itu memisahkan diri dari Sumatera bagian Selatan. Pada tahun 1956-1957 Bangka juga berupaya untuk memisahkan diri dari Provinsi Sumatera bagian Selatan. Mereka ingin membentuk provinsi sendiri, tetapi semua upaya itu belum berhasil. Masih tetap dipertahankan Sumatera Selatan. Pada tahun 2000 barulah terbentunya Provinsi Kepulauan Bangka
Belitung, yang ditetapkan berdasarkan UU No. 27 Tahun 2000.

\section{Pemekaran Provinsi Bangka Belitung}

Awal pemekaran Provinsi Bangka Belitung pada 04 Desember tahun 2000. Wilayahnya hanya 3 daerah yaitu: Kota Pangkal Pinang, Kabupaten Bangka dan Kabupaten Belitung. Pada tahun 20003 baru terjadi pemekaran terbentuknya Kabupaten Bangka Selatan, Bangka Barat, Bangka Tengah dan Belitung Timur, sehingga sekarang Bangka terdiri atas 6 kabupaten dan 1 kota. Ketika bergabung dengan provinsi Sumatera Selatan, Bangka Belitung hanya 3 wilayah otonomi Kota Pangkal Pinang, Kabupaten Bangka dan Kabupaten Belitung. Secara politis pejabat pemerintahan di Bangka dan Belitung adalah orang-orang dropping dari Palembang Daerah Daratan Sumatera, kemudian wilayah Bangka Belitung sendiri kurang terperhatikan, dianggap sebagai pulau yang terpisah dari daratan pulau Sumatera. Bangka Belitung baru diperhatikan ketika berbuat sedikit nakal, onar atau terjadi wabah penyakit baru diperhatikan. Karena provinsi induknya ada di Pulau Sumatera (Hasil wawancara Oleh Bapak Elvian, 28 Mei 2019).

Provinsi Kepulauan Bangka Belitung atau biasa disingkat Babel merupakan provinsi ke-31 di Indonesia, sebelumnya merupakan bagian dari Provinsi Sumatera Selatan. Dasar hukum penetapan Provinsi Kepulauan Bangka Belitung adalah UU No. 27 Tahun 2000 tanggal 21 November 2000 yang terbagi kedalam tiga wilayah administratif, yaitu Kabupaten Bangka, Kabupaten Belitung dan Kota Pangkal Pinang. Kemudian, di tahun 2003 dilakukan pemekaran wilayah dengan penambahan empat kabupaten yaitu Bangka Barat, Bangka Tengah, Bangka Selatan dan Belitung Timur. Hal ini didasarkan pada UU No. 5 Tahun 2003 tanggal 23 Januari 2003 (Elvian, 2016: 34). 


\section{Sejarah Kota Pangkal Pinang}

Sejarah Pangkal Pinang secara mendasar tidak dapat dipisahkan dari pengaruh kekuasaan Kekaisaraan Tiongkok di Asia Timur dan perebutan, penguasaan atau eksploitasi terhadap biji timah oleh berbagai bangsa. Sebagai bukti dari kedua hal tersebut di atas dapat dilihat dari monumen hidup (living monument), diantaranya terdapat kelenteng yang tersebar hampir di setiap rumah orang Cina dan di seluruh pelosok kota dalam ukuran besar dan kecil sesuai dengan fungsi dan pengunaanya (Elvian, 2016: 22).

Pangkal pinang mulai disebut dalam literatur sekitar abad 17 Masehi, toponim Pangkal Pinang secara etimologis berasal dari kata pangkal atau pengkal dalam bahasa Bangka yang berarti pusat distrik (distric capital), kota tempat pasar (Market Town), tempat berlabuh kapal (a but landing) dan pusat segala aktifitas dimulai (where a path bigin). Sebagai pusat segala aktifitas di atas sebutan Pangkal atau Pengkal juga digunakan oleh orang Bangka untuk penyebutan daerah-daerah seperti Pangkal Buloh, Pangkal Raya, Pangkal Menduk, Pangkal Mangas, Pangkal Lihat yang kemudian menjadi Sungai Lihat atau Sungai Liat sekarang disamping sebutan Pangkal Pinang sendiri (Elvian, 2016: 23).

Sedangkan Pinang (areca chatecu) adalah nama sejenis tumbuhan palam yang multi fungsi dan banyak tumbuh di Bangka. Jadi penamaan Pangkal Pinang dimulai dari terbentuknya kampung kecil yang banyak ditumbuhi pohon pinang. $\mathrm{Di}$ tengah kampung kecil tersebut mengalir sungaisungai yang airnya bening. Banyak perahu atau Wangkang yang keluar masuk dari kampung kecil itu dan ditepi sungai-sungai tersebut banyak pula ditumbuhi pohon pinang. Oleh pengguna perahu atau wangkang, pohon pinang tersebut digunakan untuk menambat perahu mereka ketika berlabu (Elvian, 2016: 23).

\section{Respon Guru dan Penerapan dalam Pembelajaran di SMA Negeri 1 Lepar Pongok}

Setelah peneliti melakukan penelitian di SMA Negeri 1 Lepar Pongok di kelas XI dalam pelajaran Sejarah Nasional Indonesia dengan menerapkan materi sejarah terbentuknya Provinsi Kepulauan Bangka Belitung, yang terletak di Tanjung Labu. Setelah dilakukan wawancara siswa-siswi di kelas XI tertarik untuk mengetahui sejarah terbentuknya Provinsi Kepulauan Bangka Belitung. Selain itu siswa-siswi juga bisa mengetahui awal pemekaran Provinsi Bangka Belitung dan jumlah kabupaten yang ada di Bangka Belitung (Hasil wawancara oleh Bapak Elvian, 28 Mei 2019).

\section{Hasil Penerapan Sejarah Terbentuknya Provinsi Kepulauan Bangka Belitung (Pangkal Pinang) Sebagai Sumber Pembelajaran Sejarah di SMA Negeri 1 Lempar Pongok}

Menurut ibu Mei Elfrida Tarigan guru mata pelajaran sejarah, pembelajaran sejarah di SMA Negeri 1 Lepar Pongok menggunakan Kurikulum 2013 yang termasuk dalam KD 1.1 yaitu menghayati nilai-nilai persatuan dan keinginan bersatu dalam perjuangan pergerakan nasional menuju kemerdekaan bangsa sebagai karunia Tuhan Yang Maha Esa terhadap bangsa dan negara Indonesia. Tujuan pembelajaran sejarah di sekolah adalah agar siswa lebih aktif dalam berpikir historis dan pemahaman sejarah dalam pelaksanaan belajar mengajar, sebelum itu guru terlebih dahulu harus ada pedoman mengajar berupa Silabus dan Rencana Pelaksanaan Pembelajaran (RPP) agar materi yang di sampaikan kepada siswa sesuai dengan kepada jenjangnya. Di samping itu untuk menarik minat siswa dalam pembelajaran sejarah perlu di adakan media pembelajaran misal berupa power point, film, gambar atau reflika-reflika peninggalan sejarah lainnya. Dari beberapa 
media tersebut guru dapat menjelaskan materi sejarah dengan peserta didik, serta dapat melakukan interaksi terhadap peserta didik, dengan tujuan untuk mengetahui apakah materi yang di ajarkan dapat dengan mudah dipahami oleh peserta didik (Hasil Wawancara oleh Mei Elfrida Trigen, 25 Mei 2019).

\section{SIMPULAN}

Berdasarkan hasil peneliti menyimpulkan pada 17 Agustus 1945 Indonesia merdeka, pada masa itu Bangka masih berada dalam wilayah Provinsi Sumatera bagian Selatan. Dua tahun kemudian terbentuknya beberapa Provinsi Sumatera bagian Selatan yaitu; Provinsi Sumatera Tengah, Provinsi Sumatera Timur, dan Provinsi Sumatera Utara. Sedangkan Bangka yang termasuk Pangkal Pinang itu masuk bagian Provinsi Sumatera bagian Selatan. Ada beberapa keresidenan di dalam wilayah Provinsi Sumatera bagian Selatan itu seperti: Keresidenan Lampung, Keresidenan Bengkulu, Keresidenan Bangka Belitung, Keresidenan Palembang.

Awal pemekaran Provinsi Bangka Belitung pada 04 Desember tahun 2000. Wilayahnya hanya 3 daerah yaitu; Kota Pangkal Pinang, Kabupaten Bangka dan Kabupaten Belitung. Pada tahun 2003 baru terjadi pemekaran terbentuknya kabupaten Bangka Selatan, Bangka Barat, Bangka Tengah dan Belitung Timur, sehingga sekarang Bangka terdiri atas 6 kabupaten dan 1 kota.

Provinsi Kepulauan Bangka Belitung atau biasa disingkat Babel merupakan provinsi ke-31 di Indonesia, sebelumnya merupakan bagian dari Provinsi Sumatera Selatan. Dasar hukum penetapan Provinsi Kepulauan Bangaka Belitung adalah UU No. 27 Tahun 2000 tanggal 21 November 2000 yang terbagi kedalam tiga wilayah administratif, yaitu Kabupaten Bangka, Kabupaten Belitung dan Kota Pangkal Pinang. Kemudian, di tahun 2003 dilakukan pemekaran wilayah dengan penambahan empat kabupaten yaitu Bangka Barat, Bangka Tengah, Bangka Selatan dan Belitung Timur. Hal ini didasarkan pada UU No. 5 Tahun 2003 tanggal 23 januari 2003.

Sejarah terbentuknya Provinsi Kepulauan Bangka Belitung, dapat dijadikan sebagai materi pembelajaran sejarah kelas XI yang terdapat di SMA Negeri 1 Lepar Pongok. Karena nilai sejarah dari Provinsi Kepulauan Bangka Belitung ini banyak sekali yang bisa dimanfaatkan sebagai materi pembelajaran, tetapi belum dimanfaatkan sekolah sebelumnya dengan adanya materi pembelajaran ini ternyata siswa-siswi dan guru memberi respon baik karena tertarik untuk mengetahui lebih dalam sejarah dari Provinsi Kepulauan Bangka Belitung.

\section{DAFTAR PUSTAKA}

Elvian, Ahmad. 2016. Kampoeng di Bangka Jilid I. Pangkal Pinang: CV Talenta Surya Perkasa.

2014. Setengah Abad Kota

Pangkal Pinang Sebagai Daerah

Otonom. Pangkal Pinang: CV

Persada Multi Guna.

Sugiyono. 2007. Memahami Penelitian Kualitatif. Bandung: Alfabeta.

2013. Metode Penelitian Kuantitatif, Kualitatif dan Kombiasi Mixed Methods. Bandung: Alfabeta.

Sukandarramudi. 2012. Metodologi Penelitian Petunjuk Praktis Pemula. Yogyakarta: Gaja Mada University Press.

Sutopo. 2016. Penelitian Kualitatif Dasar Teori dan Terapannya dalam Penelitian. Surakarta: Universitas Sebelas Maret. 


\section{KETENTUAN PENULISAN ARTIKEL JURNAL KALPATARU}

1. Naskah berbahasa Indonesia yang disempurnakan bertemakan kesejarah yang meliputi hasil penelitian sejarah, pengajaran sejarah dan penelitian kebudayaan.

2. Naskah harus asli dan belum pernah dimuat dalam media lain. Naskah dapat berupa hasil penelitian/artikel kajian konseptual yang ditulis oleh perorangan dan atau kelompok.

3. Naskah ditulis dengan cara-cara yang sesuai dengan ketentuan penulisan artikel ilmiah menggunakan bahasa Indonesia yang baku, berupa ketikan, beserta soft file dalam CD-RW atau dengan mengirimkan email pada redaksi jurnal Kalpataru dengan alamat jurnalkalpatarusejarah@gmail.com, spasi tunggal, jenis huruf arial narrow ukuran 12, dengan panjang naskah antara 8-15 halaman pada kertas A4.

4. Artikel hasil penelitian memuat:

JUDUL

Nama Penulis

Abstrak

\section{A. PENDAHULUAN}

B. METODE PENELITIAN

C. HASIL DAN PEMBAHASAN

D. SIMPULAN

DAFTAR PUSTAKA
: XXX (HURUF KAPITAL)

: (disertai jabatan, institusi, dan email)

: (Bahasa Indonesia yang memuat 100-200 kata diikuti kata kunci, dengan jenis huruf arrial narrow dan ukuran huruf 11 serta dicetak miring).

: (memuat latar belakang masalah, tinjauan pustaka secara ringkas, masalah penelitian, dan tujuan penelitian).

5. Artikel Kajian Konseptual memuat:

JUDUL
Nama Penulis
Abstrak
PENDAHULUAN
Sub Judul
Simpulan
DAFTAR PUSTAKA

: (berisi simpulan).

: (berisi pustaka yang dirujuk dalam uraian naskah).

6. Referensi sumber dalam teks artikel ditulis dengan menggunakan side note, contoh (Jalaludin, 1991:79); sementara penulisan daftar pustaka disusun dengan ketentuan. Nama pengarang. Tahun terbit. Judul (dicetak miring). Kota terbit: Nama Penerbit. Contoh: Koentjaraningrat. 2010. Manusia dan Kebudayaan di Indonesia. Jakarta: Djambatan. Daftar pustaka hanya memuat pustaka/sumber yang dirujuk dalam uraian dan disusun menurut abjad tanpa nomor urut.

7. Naskah yang dimuat akan disunting kembali oleh redaksi tanpa mengubah isinya.

8. Naskah yang ditolak (tidak bisa dimuat) akan dikirim kembali ke penulis dengan pemberitahuan tertulis dari redaksi atau melalui email.

9. Penulis yang naskahnya dimuat akan mendapat 1 (satu) majalah nomor yang bersangkutan.

10. Kontak person: Muhamad Idris (081271498618); Eva Dina Chairunisa (082281267851); Jeki Sepriady (085269261780). 